\title{
Kompetensi Wirausaha yang Mendorong Keberhasilan Usaha (Studi pada IKM Produk Makanan Olahan Di Provinsi Nusa Tenggara Barat)
}

\author{
*Santi Nururly, Mukmin Suryatni, M. Ilhamuddin
}

Fakultas Ekonomi dan Bisnis, Universitas Mataram

*Corresponding Author: sruly.mtr@unram.ac.id

\begin{tabular}{|c|c|}
\hline Info Artikel & ABSTRAK \\
\hline $\begin{array}{l}\text { Kata Kunci: } \\
\text { Kompetensi, Wirausaha, Keber- } \\
\text { hasilan }\end{array}$ & $\begin{array}{l}\text { Penelitian ini bertujuan untuk menganalisis hubungan kompetensi } \\
\text { wirausaha yang mendorong keberhasilan Industri Kecil dan Menengah (IKM) pen- } \\
\text { golahan makanan di Provinsi Nusa Tenggara Barat (NTB). Jenis penelitian asosiatif, } \\
\text { dengan menggunakan teknik non probability sampling. Unit analisis adalah IKM } \\
\text { yang ada di Provinsi NTB, yang mencakup wilayah Pulau Lombok, terdiri dari: Lom- } \\
\text { bok Barat, Kota Mataram, Lombok Tengah, Lombok Timur, Lombok Utara, dan } \\
\text { Wilayah Pulau Sumbawa; Sumbawa Besar. Responden penelitian adalah pemilik } \\
\text { atau pengelola usaha IKM yang diperoleh dengan cara purposive sampling yaitu } \\
\text { pemilihan sampel dengan kriteria tertentu. Dalam penelitian ini responden adalah } \\
\text { IKM yang telah berdiri lebih dari } 3 \text { (tiga) tahun dengan pendapatan positif. Jumlah } \\
\text { Responden dalam penelitian ini sebanyak } 101 \text { pengusaha. Teknik analisis data } \\
\text { dengan menggunakan SPSS. Hasil penelitian menunjukkan terdapat hubungan yang } \\
\text { signifikan antara kompetensi wirausaha dengan keberhasilan usaha pada IKM pen- } \\
\text { golahan makanan di Provinsi NTB. }\end{array}$ \\
\hline
\end{tabular}

ABSTRACT

\section{PENDAHULUAN}

Usaha Mikro dan Kecil (UMK) di Nusa Tenggara Barat yang mendominasi aktivitas ekonomi dengan proposi sekitar 99.17 persen dengan penyerapan tenaga kerja sebanyak 1.3 juta pekerja atau 92,46 persen (BPS, 2016).

Berdasarkan riset World Bank, terdapat empat permasalahan utama yang dihadapi UMKM secara nasional yaitu aspek pembiayaan, aspek peluang usaha, kapasitas Sumber Daya Manusia (SDM) dan kelembagaan UMKM, serta regulasi dan birokrasi. Pengembangan UMKM perlu didukung oleh 4 (empat) faktor utama yg diperlukan yaitu; (1) tenaga kerja, (2) modal yang tidak harus selalu dalam bentuk uang namun dalam bentuk asset intangible seperti pengetahuan atau penemuan yang inovatif, (3) teknologi penunjang seperti internet, dan (4) dukungan regulasi dari pemerintah.

Keterkaitan dengan sumberdaya manusia, maka pemberdayaan wirausaha berkaitan langsung dengan kehidupan dan peningkatan kesejahteraan bagi pembangunan daerah sekitar dengan menggali potensi strategis yang dimiliki oleh UMKM (Mahmud \& Sidharta, 2013).

Selain itu potensi dan peran wirausaha telah terbukti menjadi dapat bertahan terhadap berbagai krisis ekonomi. Keberadaan pelaku UMKM yang dominan merupakan subyek vital pembangunan, khususnya dalam rangka 


\section{Elastisitas - Jurnal Ekonomi Pembangunan \\ Vol. 2 No. 1, Maret 2020}

pembangunan kususnya dalam rangka perluasan kesempatan berusaha bagi wirausaha baru dan penyerapan tenaga kerja yang akan mengurangi pengangguran.

Industri di Nusa Tenggara Barat sampai awal tahun 2019 masih banyak dalam kategori Industri Kecil. Indikatornya adalah jumlah karyawan yang bekerja masih di bawah 19 orang dan investasi di bawah Rp. 1 Milyar. Usaha masih menggunakan teknologi tradisional, sehingga produktivitas kerja masih terbatas,

Pengembangan industri unggulan Provinsi NTB mengacu pada potensi ekonomi daerah dan keterkaitan dengan industri penunjang, industri terkait dan industri di provinsi lain. Adapun industri unggulan pada industri kerajinan dan makanan; industri pengolahan berbasis sapi, jagung, rumput laut dan pengolahan berbasis ikan unggulan. Selain itu Provinsi NTB sebagai daerah tujuan wisata sangat mendukung untuk tumbuh suburnya peluang usaha bagi industri pengolahan makanan yang mengacu pada potensi daerah.

Keberhasilan dari usaha ditunjukkan dengan mampu bertahan dengan menunjukkan proforma financial dan non-financial yang dapat memberikan kesejahteraan bagi entrepreneur. Seorang entrepreneur memegang peranan penting dalam organisasi yang dibangun. Keputusan dan aktivitas yang diambil mendorong usahanya bertahan dan dapat berkelanjutan. (Mitchelmore \& Rowley, 2010).

Banyaknya UMKM yang tumbuh dan berkembang di Provinsi Nusa Tenggara Barat, namun banyak juga yang tidak berhasil dan mati. Keterbatasan dari UMKM adalah terbatasnya kemampuann wirausaha, terbatasnya jaringan usaha, lemahnya mengakses sumber permodalan bagi UMKM, belum memadai peralatan produksi, belum optimalnya kemampuan desain dan kemasan, terbatasnya pemasaran UMKM, kurangnya sarana dan prasarana. Kendala ini berhubungan dengan kompetensi dari wirausaha.

Penelitian tentang perspektif kewirausahaan telah banyak dilakukan, namun masih banyak hal yang masih perlu untuk dianalisis, salah satunya dari aspek kompetensi sumber daya manusia yang mempengaruhi rendahnya produktivitas berkaitan dengan rendahnya kualitas sumber daya manusia (Susilo, 2010).

Oleh karena itu penelitian ini bertujuan untuk menganalisis hubungan antara kompetensi wirausaha yang mendukung keberhasilan usaha IKM Produk Makanan Olahan di Provinsi NTB dalam kondisi lingkungan yang dinamis.

\section{Pengembangan Hipotesis}

Penelitian dilaksanakan untuk menganalisis kompetensi wirausaha yang diadopsi oleh penelitian Robles dan Zarraga (2015); resiko, otonomi. Mencari informasi, kualitas kerja, komunikasi, percaya diri, mengembangkan jaringan social, dinamis, perubahan manajemen, inisiatif, inovasi, integritas, kepemimpinan, kontrol diri, orientasi pada hasil, social mobility, negosiasi, troubleshooting, tanggungjawab dan mampu bekerja dalam tim. Sedangkan keberhasilan usaha ditunjukkan dengan teori yang dilakukan oleh Islam, Keawchana dan Yusuf (2010) menyatakan bahwa untuk mengukur keberhasilan usaha meliputi: kelangsungan hidup, laba, laba atas investasi, pertumbuhan penjualan, jumlah pekerja, kebahagiaan, reputasi

\section{METODE PENELITIAN}

Jenis penelitian yang digunakan dalam ini adalah penelitian asosiatif. Dalam hal ini digunakan untuk mengetahui pengaruh antara kompetensi wirausaha terhadap keberhasilan usaha.

Populasi dalam penelitian ini adalah Industri Kecil dan Menengah (IKM) yang bergerak dibidang pengolahan makanan yang berada di Provinsi Nusa Tenggara Barat (NTB), sebagai unit analisis. Sampel ditentukan dengan metode purposive sampling dengan kriteria perusahaan yang telah berjalan 3 (tiga) tahun dan memiliki laba yang positif. Adapun responden penelitian adalah pemilik/pengelola usaha IKM pengolahan makanan sebanyak 


\section{Elastisitas - Jurnal Ekonomi Pembangunan}

Vol. 2 No. 1, Maret 2020

101 pengusaha. Analisis data menggunakan regresi linier sederhana dengan aplikasi SPSS.

Pengumpulan data menggunakan desain survey yang diperoleh secara langsung dari lapangan dengan menggunakan angket berupa kuesioner melalui wawancara pada pemilik/pengelola usaha IKM produk makanan olahan di Provinsi NTB.

Prosedur pengolahan data dengan menggunakan analisis kuantitatif dengan menggunakan pengukuran skala likert untuk masing-masing variabel.

Bobot atau skor dan kriteria dari point tersebut dalam penelitian ini adalah sebagai berikut :

1. Untuk alternative jawaban dengan kriteria sangat setuju (SS) diberi skor 5.

2. Untuk alternative jawaban dengan kriteria setuju (S) diberi skor 4.

3. Untuk alternative jawaban dengan kriteria netral $(\mathrm{N})$ diberi skor 3.

4. Untuk alternative jawaban dengan kriteria tidak setuju (TS) diberi skor 2 .

5. Untuk alternative jawaban dengan kriteria Sangat tidak setuju (STS) diberi skor 1.

Table 1. Kategori Pembobotan dan Kategori

\begin{tabular}{|l|l|l|}
\hline \multicolumn{1}{|c|}{ Bobot } & \multicolumn{2}{c|}{ Kategori } \\
\hline & Var. bebas & Var. Terikat \\
\hline $4,20-5,00$ & Sangat Tinggi (ST) & Sangat Sukses (SS) \\
\hline $3,40-4,19$ & Tinggi (T) & Sukses (S) \\
\hline $2,60-3,39$ & Cukup Tinggi (CT) & Cukup Sukses (CS) \\
\hline $1,80-2,59$ & Rendah (R) & Kurang Sukses (KS) \\
\hline $1,00-1,79$ & $\begin{array}{l}\text { Sangat Rendah } \\
\text { (SR) }\end{array}$ & Gagal (G) \\
\hline
\end{tabular}

\section{HASIL DAN PEMBAHASAN}

Hasil Peneltian

Dari hasil penelitian diperoleh gambaran responden yang tertuang pada tabel 2

\begin{tabular}{|l|r|r|}
\hline \multicolumn{1}{|c|}{ Jenis kelamin } & \multicolumn{1}{c|}{ Jumlah } & \multicolumn{1}{c|}{ \% } \\
\hline -Laki-laki & 49 & 48,5 \\
\hline -Perempuan & 52 & 51.5 \\
\hline Umur Responden & & \\
\hline 20-30 tahun & 7 & 6.9 \\
\hline $31-40$ tahun & 50 & 49.5 \\
\hline $41-50$ tahun & 36 & 35.6 \\
\hline $50 \geq$ & 8 & 7.9 \\
\hline Tingkat Pendidikan & & \\
\hline SD & 3 & 3 \\
\hline
\end{tabular}

\begin{tabular}{|l|l|l|}
\hline \multicolumn{1}{|c|}{ Jenis kelamin } & \multicolumn{1}{c|}{ Jumlah } & \multicolumn{1}{c|}{$\%$} \\
\hline SMP & 14 & 13.9 \\
\hline SMA & 63 & 62.4 \\
\hline S1 & 21 & 20.8 \\
\hline Lama Usaha & & \\
\hline $3-6$ tahun & 68 & 67.3 \\
\hline $7-10$ tahun & 19 & 18.8 \\
\hline Lebih 10 tahun & 14 & 13.9 \\
\hline Kekayaan (Asset) & & \\
\hline < 50 juta & 95 & 95 \\
\hline $\mathbf{5 0}$ Juta & 2 & 2 \\
\hline$>\mathbf{5 0}$ juta & 3 & 3 \\
\hline Pendapatan & & \\
\hline$\leq 10$ Juta & 27 & 26.7 \\
\hline $\mathbf{1 1 - 2 0}$ juta & 50 & 49.5 \\
\hline $\mathbf{2 1 - 3 0}$ juta & 21 & 20.8 \\
\hline $\mathbf{3 1 - 4 0}$ juta & 2 & 2 \\
\hline$>\mathbf{4 0}$ juta & 1 & 1 \\
\hline Sumb: Data
\end{tabular}

Sumber: Data diolah

Jenis kelamin responden terbesar perempuan dibandingkan laki-laki. Hal ini karena usaha olahan makanan biasanya memang didominasi oleh perempuan. Dalam penelitian perempuan yang mengelola usaha dan dibantu oleh suaminya.

Umur responden yang terbesar di kisaran usia 31 sampai dengan 40 tahun sebanyak 49.5\%. Usia ini memang menunjukkan usia produktif, dan kematangan dalam memiliki usaha dan mengelolanya. Sedangkan usia 21 samai 30 tahun yang paling sedikit

Tingkat Pendidikan responden terbanyak SMA sebesar $62.4 \%$ dan terendah SD sebanyak 3\%. Hal ini menggambarkan tbahwa tingkat Pendidikan para pengelola usaha sudah memiliki latar belakang Pendidikan SMA, bahkan perguruan tinggi menduduki jumlah terbanyak kedua setelah tingkat Pendidikan SMA.

Dalam penelitian ini dibatasi yang dijadika responden adalah pengusaha atau pemilik yang telah memiliki usaha lebih dari 3 tahun. Hasil penelitian menunjukkan kisaran 36 tahun yang terbanyak $67.3 \%$, sedangkan yang menjalankan usaha lebih dari 10 tahun terkecil $13.9 \%$

Dalam penelitiann ini kekayaan digambarkann dengan harta digunakan untuk opersional usaha sehari-hari, diluar dari harta tetap, seperti tempat usaha dan tanah. Ternyata 


\section{Elastisitas - Jurnal Ekonomi Pembangunan \\ Vol. 2 No. 1, Maret 2020}

hampir semua pengusaha (95\%) memiliki kekayaan di bawah 50 juta, sehingga dikategori industri kecil, sedangkan yang memiliki kekayaan lebih dari 100 juta hanya 3\%. Tabel memperlihatkan sebaran responden berdasarkan harta kekayaan.

Pendapatan responden penelitian yang terbesar di kisaran 11 sampai dengan 20 juta sebesar $49.5 \%$ hamper $50 \%$ dari responden yang ada. Sedangkan yang mendapatkan lebih dari 40 juta hanya 1 pengusaha.

Dalam penelitian ini terdiri dari 20 item pernyataan kompetensi wirausaha.

Berdasarkan Tabel 4.8. diketahui bahwa responden yang memberikan jawaban dengan rataan sebesar 4.11 yang menunjukkan kategori tinggi. Yang artinya bahwa kompetensi wirausahan memang diperlukan. Nilai kategori yang tinggi pada kompentensi wirausaha (KW 8=4.74) yaitu pengusaha harus memiliki tanggung jawab dan terendah yaitu kompetensi wirausaha $(\mathrm{KW} 12=3.54)$ yang mampu menerima keadaan tidak menentu dan mengendalikan emosi.

Tabel 3. Distribsi Jawaban Komptensi Wirausaha

\begin{tabular}{|l|l|l|}
\hline \multicolumn{1}{|c|}{ Indikator } & Rataan & \multicolumn{1}{c|}{ Kategori } \\
\hline KW1 & 4.46 & Sangat Tinggi \\
\hline KW2 & 4.21 & Sangat Tinggi \\
\hline KW3 & 4.20 & Sangat Tinggi \\
\hline KW4 & 4.28 & Sangat Tinggi \\
\hline KW5 & 4.03 & Tinggi \\
\hline KW6 & 4.26 & Sangat Tinggi \\
\hline KW7 & 4.59 & Sangat Tinggi \\
\hline KW8 & 4.74 & Sangat Tinggi \\
\hline KW9 & 4.41 & Sangat Tinggi \\
\hline KW10 & 3.89 & Tinggi \\
\hline KW11 & 3.84 & Tinggi \\
\hline KW12 & 3.54 & Tinggi \\
\hline KW13 & 3.62 & Tinggi \\
\hline KW14 & 3.71 & Tinggi \\
\hline KW15 & 3.79 & Tinggi \\
\hline KW16 & 3.72 & Tinggi \\
\hline KW17 & 4.01 & Tinggi \\
\hline KW18 & 4.27 & Sangat Tinggi \\
\hline KW19 & 4.35 & Sangat Tinggi \\
\hline KW20 & 4.36 & Sangat Tinggi \\
\hline Rataan & 4.11 & \\
\hline
\end{tabular}

Sumber: data di olah
Dari hasil sebaran kepada responden diperoleh bahwa rata-rata kategori variable terikat keberhasilan usaha 4.16 yang berada pada kategori rata-rata berhasil atau sukses. Keberhasilan usaha menurut responden tertinggi dilihat pada kriteria mendapatkan laba (KU 5, dengan skor 4.66) dan yang terendah menerut responden meningkat jumlah tenaga kerja pada KU 9 dengan kriteria 3.47. Walapun semuanya masih dalam kategori sukses

Tabel 4. Distribusi Jawaban Keberhasilan Usaha

\begin{tabular}{|l|l|l|}
\hline \multicolumn{1}{|c|}{ Indikator } & \multicolumn{1}{c|}{ Rataan } & \multicolumn{1}{c|}{ kategori } \\
\hline 47 & 4.42 & Sangat Sukses \\
\hline 53 & 4.47 & Sangat Sukses \\
\hline 29 & 4.19 & Sukses \\
\hline 37 & 4.30 & Sangat Sukses \\
\hline 29 & 4.66 & Sangat Sukses \\
\hline 17 & 3.82 & Sukses \\
\hline 19 & 3.83 & Sukses \\
\hline 14 & 3.70 & Sukses \\
\hline 13 & 3.47 & Sukses \\
\hline 47 & 4.40 & Sangat Sukses \\
\hline 58 & 4.52 & Sangat Sukses \\
\hline 4.16 & Sukses & \\
\hline
\end{tabular}

Dari hasil uji Validitas dan Realibilitas diperoleh hasil semua data valid dan reliabel.

Tabel 5. Hasil Uji Validitas Kompetensi Wirausaha

\begin{tabular}{|c|r|r|l|}
\hline $\begin{array}{c}\text { Item } \\
\text { Kuesioner }\end{array}$ & r-hitung & r-tabel & Kesimpulan \\
\hline 1 & 0,487 & 0,1956 & Valid \\
\hline 2 & 0,446 & 0,1956 & Valid \\
\hline 3 & 0,337 & 0,1956 & Valid \\
\hline 4 & 0,278 & 0,1956 & Valid \\
\hline 5 & 0,477 & 0,1956 & Valid \\
\hline 6 & 0,448 & 0,1956 & Valid \\
\hline 7 & 0,418 & 0,1956 & Valid \\
\hline 8 & 0,420 & 0,1956 & Valid \\
\hline 9 & 0,425 & 0,1956 & Valid \\
\hline 10 & 0,627 & 0,1956 & Valid \\
\hline 11 & 0,603 & 0,1956 & Valid \\
\hline 12 & 0,539 & 0,1956 & Valid \\
\hline 13 & 0,471 & 0,1956 & Valid \\
\hline 14 & 0,472 & 0,1956 & Valid \\
\hline 15 & 0,315 & 0,1956 & Valid \\
\hline 16 & 0,462 & 0,1956 & Valid \\
\hline 17 & 0,515 & 0,1956 & Valid \\
\hline 18 & 0,484 & 0,1956 & Valid \\
\hline 19 & 0,503 & 0,1956 & Valid \\
\hline 20 & 0,235 & 0,1956 & Valid \\
\hline
\end{tabular}

Sumber:Data diolah 


\section{Elastisitas - Jurnal Ekonomi Pembangunan \\ Vol. 2 No. 1, Maret 2020}

Pada tabel $\mathrm{Y}=$ Keberhasilan Usaha di atas diketahui bahwa semua item pertanyaan adalah valid karena $r$ hitung $>r$ tabel, dimana $r$ tabel dalam penelitian ini sebesar 0,1956 sesuai dengan tabel $r$ product moment dengan jumlah responden 101 orang dan taraf signifikansi 5 persen. Dengan seluruh item pertanyaan pada variabel $Y$ yang valid maka seluruh item pertanyaan dapat digunakan.

Tabel 6. Hasil Uji Validitas Keberhasilan Usaha

\begin{tabular}{|l|r|r|l|}
\hline $\begin{array}{c}\text { Item } \\
\text { kuesioner }\end{array}$ & r- hitung & r- table & Kesimpulan \\
\hline 1 & 0,607 & 0,1956 & Valid \\
\hline 2 & 0,545 & 0,1956 & Valid \\
\hline 3 & 0,339 & 0,1956 & Valid \\
\hline 4 & 0,654 & 0,1956 & Valid \\
\hline 5 & 0,537 & 0,1956 & Valid \\
\hline 6 & 0,758 & 0,1956 & Valid \\
\hline 7 & 0,778 & 0,1956 & Valid \\
\hline 8 & 0,816 & 0,1956 & Valid \\
\hline 9 & 0,691 & 0,1956 & Valid \\
\hline 10 & 0,397 & 0,1956 & Valid \\
\hline 11 & 0,210 & 0,1956 & Valid \\
\hline
\end{tabular}

Sumber:Data diolah

Tabel 7. Hasil Uji Reliabilitas

\begin{tabular}{|c|c|c|c|}
\hline Variabel & $\begin{array}{c}\text { Nilai } \\
\text { Croncbach"s } \\
\text { Alpha }\end{array}$ & Kriteria & Status \\
\hline $\mathrm{X}$ & 0.776 & 0.600 & Reliable \\
\hline $\mathrm{Y}$ & 0.809 & 0.600 & Reliabel \\
\hline
\end{tabular}

Hasil Uji Normalitas

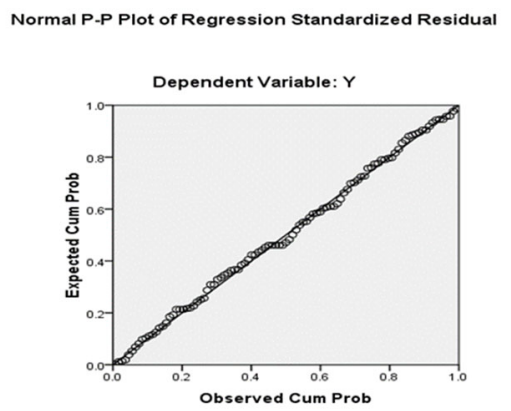

Hasil kurva probability plot pada gambar diatas memperihatkan bahwa titik - titik pada gabar grafik terlihat mengikuti garis diagonal. Sehingga berdasarkan kurva normal probability plot, data yang digunakan berdistribusi normal. Untuk memperkuat hasil uji diatas peneliti melakukan pengujian kembali dengan metode Kolmogrov-Smirnov.

Berdasarkan uji normalitas Kolmogorov-Smirnov Test diperoleh nilai KSZ sebesar 0,349 dan Asym. Sig. sebesar 1,000 dimana lebih besar dari 0,05. Oleh karena itu dapat disimpulkan bahwa data diatas berdistribusi normal.

Hasil Uji Regresi diperoleh hasil:

$$
Y=20,957+0,297 X+e
$$

Hasil persamaan regresi linier berganda dapat diuraikan sebagai berikut:

\section{a. $\quad$ Konstanta $(\alpha)=20,957$}

Nilai konstanta sebesar 20,957 menunjukkan bahwa jika variabel kompetensi Wirausha $(\mathrm{X})$ tidak mengalami perubahan atau dianggap tetap (0), maka variabel Keberhasilan Usaha (Y) akan memiliki nilai sebesar $20,957$.

b. Koefesien b1 $=0,297$

Nilai koefesien b1sebesar 0,297 menunjukkan bahwa apabila variable Kompetensi Wirausaha (X) mengalami kenaikan sebanyak satu satuan, maka vaariabel Keberhasilan Usaha (Y) juga akan mengalami kenaikkan sebesar $0,297(27,9 \%)$ satu - satuan dengan syarat variabel lain bernilai nol atau tetap. Nilai b1 bernilai positif berarti variabel Kompetensi Wirausaha $(\mathrm{X})$ dapat dinaikkan sejumlah besaran nilai koefesiennya.

Tabel 8. Hasil Uji Analisis Regresi

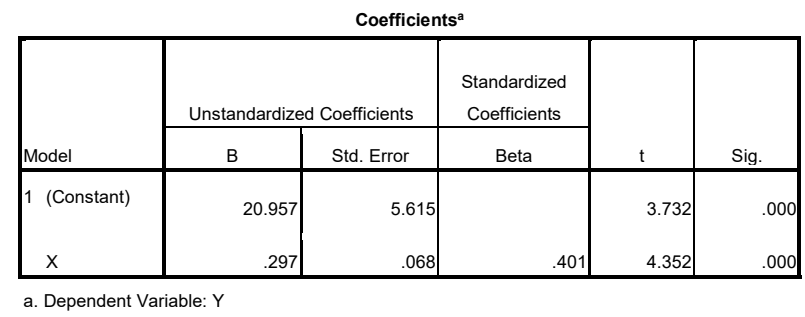

Berdasarkan hasil uji regresi pada tabel diatas, angka t hitung variabel Kompetensi Wirausaha $(X)$ sebesar 5,440. Sehingga nilai $t$ hitung $>$ t Tabel $(4,352>1,660)$ maka $\mathrm{H}_{-} 0$ ditolak, artinya terdapat pengaruh signifikan 


\section{Elastisitas - Jurnal Ekonomi Pembangunan \\ Vol. 2 No. 1, Maret 2020}

antara variabel Kompetensi Wirausaha (X) dengan peningkatan variabel Keberhasilan Usaha (Y). Hal ini didukung pula dari segi taraf signifikansinya sebesar 0,000 dimana $(0,000<0,05)$ maka dapat disimpulkan bahwa variabel Kompetensi Wirausaha (X) berpengaruh terhadap variabel Keberhasilan Usaha (Y). Berdasarkan penjelasan tersebut oleh karena itu H_0 ditolak dan $\mathrm{H}_{-} 1$ diterima, artinya terdapat hubungan linier antara variabel Kompetensi Wirausaha (X) dengan peningkatan variabel Keberhasilan Usaha (Y). Dengan demikian angka tersebut membuktikan bahwa secara parsial variabel Kompetensi Wirausaha (X) memberikan pengaruh yang signifikan terhadap variabel Keberhasialan Usaha (Y).

Tabel 9. Hasil Uji Parsial

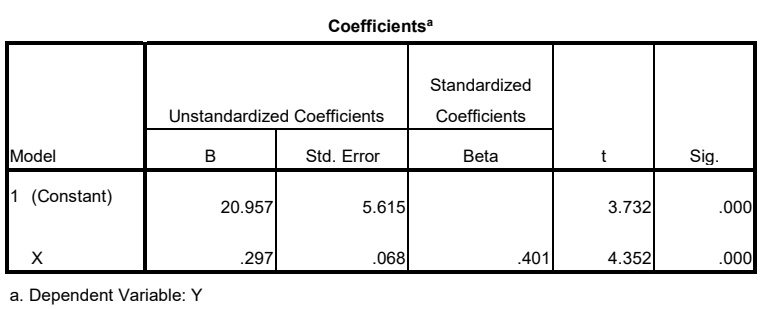

Nilai R sebesar 0,401 menunjukkan korelasi Variabel Kompetensi Wirausaha (X) dengan variable Keberhasilan Usaha (Y). Dengan mempertimbangkan variasi Nilai Adjusted dan R Square sebesar 0,161 yang menunjukkan besarnya peran atau kontribusi variabel X terhadap variabel $\mathrm{Y}$ sebesar $16,1 \%$ dan sisanya $83,9 \%$ dipengaruhi oleh variabelvariabel lain yang tidak termasuk dalam penelitian ini. Nilai determinasi kecil menunjukkan banyak faktor lain yang mempengaruhi selain kompetensi wirausaha.

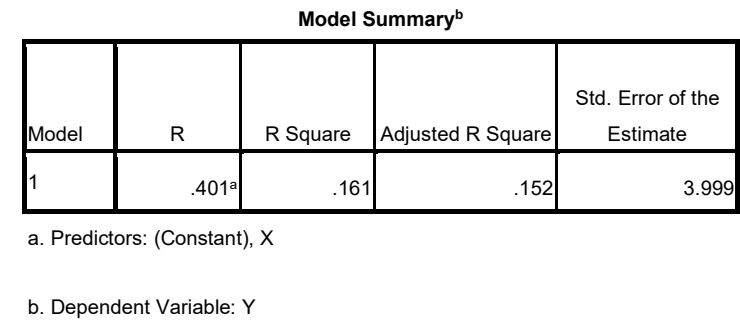

\section{KESIMPULAN\& SARAN}

Kesimpulan

Hasil penelitian yang telah membuktikan sesuai dengan hipotesis bahwa Kompetensi Wirausaha mempunyai pengaruh signifikan terhadap keberhasilan usaha

\section{Saran}

Kompetensi Wirausaha pada indikator kemampuan menyesuaikan dengan keadaan yang tidak pasti perlu ditingkatkan. Sebagaimana diketahui bahwa dunia usaha memang selalu berhubungan dengan ketidakpastian.

\section{DAFTAR PUSTAKA}

BPS. 2016. Hasil Pendaftaran Usaha/Perusahaan Sensus Usaha.

Dhamayantie, E., \& Fauzan, R. (2017). Penguatan Karakteristik dan kompetisi kewirausahaan untuk meningkatkan kinerja UMKM. Jurnal Manajemen, Strategi Bisnis Dan Kewirausahaan, 11(1), 80-91.

Hazlina Ahmad, N., Ramayah, T., Wilson, C., \& Kummerow, L. (2010). Is entrepreneurial competency and business success relationship contingent upon business environment?: A study of Malaysian SMEs. International Journal of Entrepreneurial Behaviour \& Research, 16(3), 182-203.

https://doi.org/10.1108/1355255101104 2780

Mitchelmore S. \& Rowley J. (2010) Entrepreneurial competencies. A literature review and development agenda. International Journal of Entrepreneurial Behaviour and Research, 16, 92-111.

Ng, H. S., \& Kee, D. M. H. (2017). The core competence of succesful owner-manage SMEs. Management Decision. https://doi.org/10.1108/MBE-09-20160047

Nwachukwu, C., Chladkova, H., \& Zufan, P. (2017). The Relationship between entrepreneurial orientation, entrepreneurial competencies, entrepreneurial 
leadership, and firm performance: a proposed model. Business Trends, 7(1), $3-16$.

Sidharta, I., \& Lusyana, D. (2014). Analisis faktor penentu kompetensi berdasarkan kosep knowledge, skill, dan ability (KSA) di sentra kaos suci Bandung. Jurnal Compuech \&Bisnis, 8(1), 49-60.

Susilo, Y. S. (2010). Strategi meningkatkan daya saing umkm dalam menghadapi implementasi cafta dan mea. Buletin Ekonomi, 8(2), 70-78.

Nururly, Santi. Kinerja Usaha IKM Produk Olahan Pijar. Jurnal Riset Manajemen. Vol 15 No. 1, Maret 2015

https://www.suarantb.com/headline/2019/ 02/267097/Wujud.Industrialisasi.NTB.

Bukan.Pabrik.Besar/

Peraturan menteri no. 100-2010 Roadmap Nusa Tenggara Barat. 